mercially available reagent (British Drug Houses Ltd.) contains different proportions of acid and alcohol from that recommended here.

(6). It is not recommended that volumes of plasma smaller than $2 \mathrm{ml}$ are analysed (unless the volume of the solvent and reagent is also decreased proportionately). The contribution of non-specific fluorogens becomes increasingly important as sample volume decreases, and gives spuriously high results.

(7). Purification of ethanol: $2 \frac{1}{2}$ litres of ethanol are refluxed for two hours with $12.5 \mathrm{~g}$ of $2: 4$ dinitrophenylhydrazine and $25 \mathrm{ml}$ of concentrated hydrochloric acid. Cool and distil twice (fractionating column), collecting the fraction which boils at $78^{\circ} \mathrm{C}$.

(8). Flow cells are not recommended because of the carry-over of the reagent.

(9). Occasional problems have arisen with the working standard when a sudden loss of concentration has taken place. This appears to be due to destruction or absorption of the cortisol. Though the reason for this is not apparent, it has been associated with the use of glass-distilled water from a freshly cleaned still, in which the metal element is exposed, and may be due to the presence of inorganic ions. It is also strongly recommended that the inside of the glass container in which the working standard is to be stored be carefully siliconed.
(10). If plasma samples are to be stored before analysis it is advisable that they should be deep frozen at $-20^{\circ} \mathrm{C}$. Unsatisfactory results are obtained if, after subsequent thawing, an attempt is made to remove an aliquot for analysis because of the precipitation of protein which occurs. It is recommended that a volume of plasma-that is, $2 \mathrm{ml}$-is stored and that the whole sample is subsequently extracted for analysis.

(11). Heparin solutions containing benzyl alcohol are unsuitable as anticoagulants for blood samples which are to be assayed by this method, since some specimens of benzyl alcohol have been reported to cause interference with the fluorometry.

\section{References}

James, V. H. T., Townsend, J., and Fraser, R. (1967). Fournal of Endocrin-

ology, 37, xxviii.
Mattingly, D. (1962). Fournal of Clinical Pathology, 15, 374.

Peterson, R. E., Karrer, A., and Guerra, S. L. (1957). Analytical Chemistry, $29,144$.

Silber, R. H. (1966). Methods of Biochemical Analysis, 14, 63.

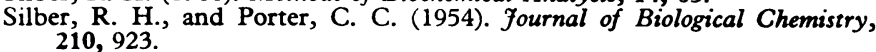

Snedecor, G. W. (1952). Biometrics, 8, 85.

\title{
Spontaneous and Persisting Decrease in Maximal Acid Output
}

\author{
H. G. DESAI, M. P. ZAVERI, F. P. ANTIA
}

British Medical fournal, 1971, 2, 313-315

\section{Summary}

A spontaneous decrease in maximal acid output was observed in three control subjects and in seven patients with duodenal ulcer. The decreased output was due to a decrease in volume and to a lower concentration in six subjects and to a decrease in volume in four subjects. In some cases the decrease in output occurred within a period of weeks. Patients with a pronounced decrease remained asymptomatic for a prolonged period.

\section{Introduction}

Variations in basal and maximal acid output in patients with Zollinger-Ellison syndrome, perhaps due to fluctuations in circulating gastrin (Winship and Ellison, 1967), and a spontaneous decrease in maximal acid output in a patient with duodenal ulcer and in a control subject (Waterfall, 1969) have been reported. But there is little information on the time taken for the decrease in acid secretion to occur, on whether it is due to a decrease in volume and/or concentration of acid, or on how often a spontaneous decrease in maximal acid output occurs in patients with duodenal ulcer. This paper reports our observations on the dose-response curves with different stimuli. They show a significant spontaneous decrease in maximal acid output in three control subjects and in seven patients with duodenal ulcer.

\footnotetext{
Pai Department of Gastroenterology, B.Y.L. Nair Charitable Hospital, Bombay 8, India

H. G. DESAI, M.D., Assistant Physician

H. G. DESAI, M.D., Assistant Physic

F. P. ANTIA, M.D., F.R.C.P., Physician in Charge
}

\section{Patients and Methods}

The three control subjects (two men, one woman) were free from gastrointestinal symptoms and had normal haemoglobin levels. The seven male patients had duodenal ulcer-a diagnosis supported by $x$-ray examination. Their average age was 35.1 (18-50) years and their average weight $46.2(38.8-62.0) \mathrm{kg}$. The patients with duodenal ulcer were given antacids, but none had prolonged treatment with anticholinergic drugs. None were given aspirin, corticosteroids, or diuretics during the period of the study.

Dose-response curves to $2.0,2.4,2.8$, and $3.2 \mathrm{mg}$ of histamine acid phosphate subcutaneously; to $2.0,2.4$, and 2.8 $\mathrm{mg} / \mathrm{hr}$ of histamine acid phospate intravenously (Desai, Zaveri and Antia 1970a); to 75, 100, and $125 \mathrm{mg}$ of ametazole hydrocloride (Histalog) subcutaneously (Desai, Zaveri, and Antia, 1970b); and to 250,300 , and $350 \mu \mathrm{g}$ of pentagastrin subcutaneously (Desai, Zaveri, and Antia, 1971) were obtained on different days, as described in previous studies. The dose-response curves for any one stimulus were completed within three weeks, but different stimuli were administered at various times according to the availability of the stimulus or the convenience of the patient. Maximal acid output was calculated by the method of Card and Marks (1960). Gastric biopsy material was obtained with a Crosby-Kugler capsule (Crosby and Kugler, 1957) either from the fundus or from the body of the stomach, and histological sections were stained with haematoxylin and eosin.

\section{Results}

The maximal acid outputs after different stimuli are given in Table $I$. The initial readings are indicated as series $A$ and 
TABle I-Maximal Acid Output (mEq/hr) with Different Stimuli. Control Subjects: Nos. 4, 5, and 10. Duodenal ulcer patients: 1-3 and 6-9

\begin{tabular}{|c|c|c|c|c|c|c|c|c|c|c|c|}
\hline \multirow{2}{*}{ Case No. } & \multirow{2}{*}{ Route } & \multicolumn{4}{|c|}{ Subcutaneous or Intravenous Histamine Tests } & \multicolumn{3}{|c|}{ Subcutaneous Ametazole Tests ${ }^{\dagger}$} & \multicolumn{3}{|c|}{ Subcutaneous Pentagastrin Tests } \\
\hline & & $2.0 \mathrm{mg}$ & $2.4 \mathrm{mg}$ & $2.8 \mathrm{mg}$ & $3.2 \mathrm{mg}$ & $75 \mathrm{mg}$ & $100 \mathrm{mg}$ & $125 \mathrm{mg}$ & $250 \mu \mathrm{g}$ & $300 \mu \mathrm{g}$ & $350 \mu \mathrm{g}$ \\
\hline\{ & $\begin{array}{l}\text { S.C. } \\
\text { I.v. }\end{array}$ & $\begin{array}{l}23 \cdot 7 \\
32 \cdot 0\end{array}$ & $\begin{array}{l}30 \cdot 6 \\
36 \cdot 0^{*}\end{array}$ & $\begin{array}{l}34 \cdot 7 \\
24 \cdot 7\end{array}$ & ${ }^{35 \cdot 2^{*}}{ }^{(\mathrm{A})}$ (A) & $26.5 *$ & $25 \cdot 4$ & $20 \cdot 3$ (B) & $17 \cdot 4$ & $26 \cdot 4^{*}$ & $24 \cdot 3$ (B) \\
\hline\{ & $\begin{array}{l}\text { S.C. } \\
\text { I.V. }\end{array}$ & $\begin{array}{l}22 \cdot 3 \\
41 \cdot 0\end{array}$ & $\begin{array}{l}23 \cdot 8 \\
43 \cdot 1^{*}\end{array}$ & $\begin{array}{l}31.7 \\
37.0\end{array}$ & $\begin{array}{l}39 \cdot 6^{*} \text { (A) } \\
\text { (A) }\end{array}$ & $34 \cdot 6$ & $32 \cdot 2$ & $45 \cdot 5^{*}(\mathrm{~A})$ & $22 \cdot 7$ & $24 \cdot 9$ & $28.5^{*}(\mathrm{~B})$ \\
\hline\{ & $\begin{array}{l}\text { s.c. } \\
\text { I.v. }\end{array}$ & $23 \cdot 3$ & $\begin{array}{l}29 \cdot 0 \\
26 \cdot 3^{*}\end{array}$ & $\begin{array}{l}32 \cdot 2 \\
24 \cdot 2\end{array}$ & $\begin{array}{l}34.3^{*} \\
-(\mathrm{B})\end{array}$ & - & $21 \cdot 6^{*}$ & $20 \cdot 4(B)$ & $19 \cdot 3$ & $21 \cdot 7^{*}$ & 20.8 (B) \\
\hline\{ & $\begin{array}{l}\text { S.C. } \\
\text { I.v. }\end{array}$ & $\begin{array}{l}14 \cdot 1 \\
22 \cdot 0^{*}\end{array}$ & $\begin{array}{l}14 \cdot 6 \\
18 \cdot 6\end{array}$ & $\begin{array}{l}17.3^{*} \\
19.6\end{array}$ & $\begin{aligned} 14.8 & \text { (A) } \\
- & (\mathrm{A})\end{aligned}$ & - & $14 \cdot 4^{*}$ & & 8.2* & 6.5 & \\
\hline 5 & $\begin{array}{l}\text { S.C. } \\
\text { I.V. } \\
\text { s.C. }\end{array}$ & $\begin{array}{l}\overline{14 \cdot 5} \\
11.3\end{array}$ & $\begin{array}{l}33 \cdot 0^{*} \\
16 \cdot 4^{*} \\
14 \cdot 0^{*}\end{array}$ & $\begin{array}{l}25.9 \\
16.0 \\
13.9\end{array}$ & $\left.\overline{14 \cdot 2} \begin{array}{l}(\mathrm{A}) \\
(\mathrm{B}) \\
(\mathrm{B})\end{array}\right)$ & $15 \cdot 3^{*}$ & $13 \cdot 4$ & $15 \cdot 1$ (B) & $19 \cdot 9^{*}$ & $15 \cdot 4$ & 14.5 (B) \\
\hline 6 & $\begin{array}{l}\text { S.C.C. } \\
\text { I.v. } \\
\text { s.c. } \\
\text { I.V. }\end{array}$ & $\begin{array}{l}24 \cdot 2 \\
36 \cdot 3 \\
19 \cdot 2 \\
26 \cdot 7\end{array}$ & $\begin{array}{l}28.8 \\
39.5 * \\
15.7 \\
29.7\end{array}$ & $\begin{array}{l}35.9^{*} \\
28.9 \\
16 \cdot 1 \\
30.2^{*}\end{array}$ & $\begin{array}{r}34.6 \text { (A) (A) } \\
22.5^{*} \text { (B) } \\
- \text { (B) }\end{array}$ & $20 \cdot 9$ & $25 \cdot 7^{*}$ & 23.1 (B) & & & \\
\hline\{ & $\begin{array}{l}\text { I.V. } \\
\text { s.C. }\end{array}$ & $\begin{array}{l}9 \cdot 6 * \\
6 \cdot 1^{*}\end{array}$ & $\begin{array}{l}8.6 \\
4.4\end{array}$ & $\begin{array}{l}9 \cdot 6 \\
5 \cdot 8\end{array}$ & $\overline{5 \cdot 2} \stackrel{(\mathrm{A})}{(\mathrm{B})}$ & & & & 6.7 & $12 \cdot 9 *$ & $12 \cdot 2(\mathrm{~A})$ \\
\hline 8 & $\begin{array}{l}\text { S.C. } \\
\text { I.v. } \\
\text { s.c. }\end{array}$ & $\begin{array}{r}25.6 \\
17.5 \\
6 \cdot 2\end{array}$ & $\begin{array}{c}28.6 \\
20.4 \\
8 \cdot 2\end{array}$ & $\begin{array}{c}31 \cdot 6^{*} \\
19.8 \\
9.4^{*}\end{array}$ & 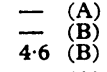 & & & & $15 \cdot 2$ & $15 \cdot 7^{*}$ & 10.7 (B) \\
\hline 9 & $\begin{array}{l}\text { S.C. } \\
\text { I.V. } \\
\text { S.C. }\end{array}$ & $\begin{array}{l}3 \overline{11.7 *} \\
15.9\end{array}$ & $\overline{\overline{17 \cdot 3}}$ & $\begin{array}{l}34.8^{*} \\
31.7 \\
20 \cdot 7^{*}\end{array}$ & 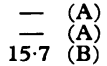 & & & & & & \\
\hline 10 & $\begin{array}{l}\text { S.C. } \\
\text { s.c. } \\
\text { s.c. }\end{array}$ & $\overline{13.5}$ & $\frac{30 \cdot 3^{*}}{8 \cdot 5^{*}}$ & $=$ & 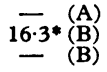 & & & & & & \\
\hline
\end{tabular}

* Highest value.

+ Average of one and two hours.

$\mathbf{A}=$ Initial readings. $\mathbf{B}=$ Readings after decrease.

those after the decrease as series $B$. The intervals before a decrease in acid output was observed (TA-TB) and the time during which series $A\left(T_{1}-T A_{2}\right)$ and series $B\left(T B_{1}-T_{2}\right)$ were completed are shown in weeks (Table II).

The readings in series B showed decreases in acid output varying from 26.7 to $71.9 \%$, compared with initial readings in series A (Table II). The decrease was due to a decrease both in volume and in concentration of acid in six cases (Nos. $2-5,8$, and 9) and in volume only in four (Cases 1, 6, 7, and 10). The time taken before a decrease in maximal acid output was observed was as short as two and five weeks in Cases 9 and 2 respectively, while in others it was after a period of months. The decrease in acid output persisted for more than four months in Cases 3, 5, 6, 8, and 10.

Four patients with duodenal ulcer (Cases 2, 3, 8, and 9) were asymptomatic for about two years after the decrease in their acid output, while the symptoms in another (Case 6) diminished but did not disappear completely, and he required surgery. In one asymptomatic patient (Case 3 ) a repeat $x$-ray examination showed a benign gastric ulcer on the lesser curvature.

\section{Discussion}

Our findings support the observation by Waterfall (1969) of a spontaneous decrease in maximal acid output in a control subject and in a patient with duodenal ulcer after a single conventional dose of a stimulus.

The decrease in maximal acid output may be due to (1) iron deficiency, causing anaemia (Davidson and Markson, 1955; Beveridge, Bannerman, Evanson, and Witts, 1965; Desai, Mehta, Borkar, and Jeejeebhoy, 1967) and/or deficiency in the iron-dependent enzyme system (Desai, Mehta, Borkar, and Jeejeebhoy, 1968); (2) salt depletion from diuretic therapy or from dietric deficiency and thus lack of chlorides for the formation of $\mathrm{HCl}$ (Kothari et al., 1969); (3) atrophic gastritis; and (4) the conventional dose of histamine acid phosphate in relation to body weight providing submaximal stimulation in "underweight" subjects. Low outputs of acid are seen in persons weighing less than $60 \mathrm{~kg}$ (Desai, Borkar, and Jeejeebhoy, 1967). None of our subjects developed anaemia, were given diuretics, or lacked salt in their diet. The decrease in maximal acid output in some cases was seen within a few

TABLE II-Reduction in Maximal Acid Output, Volume, and/or Average Concentration. Control Subjects: Nos. 4, 5, and 10. Duodenal ulcer Patients: $1-3$ and $6-9$

\begin{tabular}{|c|c|c|c|c|c|c|c|c|c|c|c|c|}
\hline \multirow{2}{*}{$\begin{array}{l}\text { Case } \\
\text { No. }\end{array}$} & \multicolumn{3}{|c|}{$\underset{(\mathrm{mEq} / \mathrm{hr})}{\operatorname{Maximal} \text { Acid Output }}$} & \multicolumn{3}{|c|}{$\underset{(\mathrm{ml})}{\text { Volume }}$} & \multicolumn{3}{|c|}{$\begin{array}{l}\text { Average Concentration } \\
(\mathrm{mEq} / \mathrm{l})\end{array}$} & \multicolumn{3}{|c|}{$\begin{array}{l}\text { Time Interval } \\
\text { (Weeks) }\end{array}$} \\
\hline & A & B & Reduction \% & $\mathbf{A}$ & B & Reduction \% & A & B & Reduction $\%$ & TA-TB & $T A_{1}-T_{A}$ & $\mathrm{~TB}_{1}-\mathrm{TB}_{2}$ \\
\hline $\begin{array}{c}1 \\
2 \\
3 \\
4 \\
5^{*} \\
6 \\
7 \\
8 \\
9 \\
10^{*}\end{array}$ & $\begin{array}{l}36 \cdot 0 \\
45 \cdot 5 \\
34 \cdot 3 \\
22 \cdot 0 \\
33 \cdot 0 \\
39 \cdot 5 \\
12 \cdot 9 \\
31 \cdot 6 \\
34 \cdot 8 \\
30 \cdot 3\end{array}$ & $\begin{array}{r}26.4 \\
28.5 \\
21.6 \\
8.2 \\
14.0 \\
22.5 \\
6.1 \\
9.4 \\
20.7 \\
8.5\end{array}$ & $\begin{array}{l}26.7 \\
37.4 \\
37.0 \\
62.8 \\
57.6 \\
43.0 \\
52.7 \\
70.3 \\
40.5 \\
71.9\end{array}$ & $\begin{array}{l}390 \\
462 \\
370 \\
180 \\
360 \\
413 \\
152 \\
290 \\
300 \\
335\end{array}$ & $\begin{array}{r}259 \\
430 \\
330 \\
150 \\
280 \\
280 \\
77 \\
137 \\
243 \\
160\end{array}$ & $\begin{array}{r}33 \cdot 6 \\
6.9 \\
10 \cdot 8 \\
16 \cdot 7 \\
22 \cdot 2 \\
32 \cdot 2 \\
49 \cdot 3 \\
52 \cdot 8 \\
19 \cdot 0 \\
52 \cdot 2\end{array}$ & $\begin{array}{r}92.5 \\
93.0 \\
92.0 \\
105.0 \\
92.0 \\
96.5 \\
81.5 \\
107.5 \\
105.5 \\
87.5\end{array}$ & $\begin{array}{r}109.5 \\
82.0 \\
65.5 \\
52.5 \\
46.0 \\
108.0 \\
76.0 \\
66.5 \\
83.0 \\
83.5\end{array}$ & $\begin{array}{r}\overline{11 \cdot 8} \\
28 \cdot 8 \\
50 \cdot 0 \\
50 \cdot 0 \\
\overline{6 \cdot 7} \\
38 \cdot 1 \\
21 \cdot 3 \\
4 \cdot 6\end{array}$ & $\begin{array}{r}8 \\
5 \\
60 \\
16 \\
16 \\
32 \\
12 \\
88 \\
2 \\
28\end{array}$ & $\begin{array}{r}10 \\
22 \\
1 \\
3 \\
1 \\
6 \\
20 \\
1 \\
4 \\
-\end{array}$ & $\begin{array}{r}12 \\
3 \\
48 \\
8 \\
20 \\
34 \\
3 \\
48 \\
14 \\
120\end{array}$ \\
\hline
\end{tabular}

* Atrophic gastritis on gastric biopsy after series B.

A Atrophic gastritis

$\mathrm{A}=$ Initial readings.

TA-TB = Interval between series A and series $B$

$\mathrm{TA}_{1}-\mathrm{TA}_{2}=$ Time taken to complete series A.
$\mathrm{TB}_{1}-\mathrm{TB}_{2}=$ Time taken to complete series $\mathrm{B}$. 
weeks, and atrophic gastritis could not have developed so rapidly. Nevertheless, this possibility could not be excluded in other cases (Nos. 4, 5, 7, 8, and 10) in which the decrease started gradually after a period of months. Gastric biopsy suggested atrophic gastritis in Cases 5 and 10.

A decrease in maximal acid output may perhaps be an explanation for the prolonged remissions observed in some cases of duodenal ulcer. The spontaneous decrease seen in patients with duodenal ulcer suggests that the larger parietal cell mass in these patients is probably acquired and not inherited.

A decrease in acid ouput in patients with duodenal ulcer after prolonged administration of anticholinergic drugs has been attributed to the drug (Hunt and Wales, 1966) or to a spontaneous fluctuation in parietal cell mass independently of the drug (Kaye, Beck, Rhodes, and Sweetman, 1969). Since a spontaneous decrease in maximal acid output is not uncommon in patients with duodenal ulcer, as shown by this study, caution should be exercised before attributing a decrease in acid output to the drug administered.
Part of this study was aided by a grant from B.Y.L. Nair Charitable Hospital and T.N.M.C. Research Society.

\section{References}

Beveridge, B. R., Bannerman, R. M., Evanson, J. M., and Witts, L. J. (1965). Quarterly fournal of Medicine, 34, 145.

Card, W. I., and Marks, I. N. (1960). Clinical Science, 19, 147.

Crosby, W. H., and Kugler, H. W. (1957). American fournal of Digestive Diseases, 2,236

Davidson, W. M. B., and Markson, J. L. (1955). Lancet, 2, 639.

Desai, H. G., Borkar, A. V., and Jeejeebhoy, K. N. (1967). Gastroenterology, 53,712 .

Desai, H. G., Mehta, B. C., Borkar, A. V., and Jeejeebhoy, K. N. (1967) Indian fournal of Medical Research, 55, 1051.

Desai, H. G., Mehta, B. C., Borkar, A. V., and Jeejeebhoy, K. N. (1968). Gut, 9,91 .

Desai, H., G., Zaveri, M. P., and Antia, F. P. (1970a). Gastroenterology, $59,701$.

Desai, H. G., Zaveri, M. P., and Antia, F. P. (1970b). Indian fournal of Medical Research, 58, 202 .

Desai, H. G., Zaveri, M. P., and Antia, F. P. (1971). Unpublished.

Hunt, J. N., and Wales, R. C. (1966). British Medical fournal, 2, 13.

Kaye, M. D., Beck, P., Rhodes, J., and Sweetman, P. M. (1969). Gut, 10,774 .

Kothari, M. L., et al. (1969). Gut, 10, 71.

Waterfall, W. (1969). British Medical fournal, 4, 459.

Winship, D. H., and Ellison, E. H. (1967). Lancet, 1, 1128.

\title{
Termination of Pregnancy by the Intrauterine Insertion of Utus Paste
}

\author{
S. V. SOOD
}

British Medical fournal, 1971, 2, 315-317

\section{Summary}

Utus paste was used to induce abortion in 83 women. It was successful in all but two. Pain was a prominent symptom in many cases. Complications included three cases of septicaemia and one of perforation of the uterus leading to death. This experience shows the complications of abortion induced by Utus paste to be too serious to justify its further use.

\section{Introduction}

Medicated soft soaps for the induction of abortion by intrauterine injection were invented in Germany in the 1930s. Their use spread to America and later to Britain after Browne (1946) and Barnes (1946) had drawn attention to them. This has been the method of choice in St. Helier Hospital, Carshalton, for the past 20 years (Lachelin and Burgess, 1968).

Abortifacient pastes have been in and out of favour ever since they were first used. Large-scale studies are, unfortunately, not available for reliable evidence and fuller assessment of their usefulness. Engelmann (1932a, 1932b) studied cases of criminal abortion in which pregnancy was terminated with Interruptin and he noted 12 deaths due to fat embolism and five due to air embolism. Weilerstein (1944) reported two cases in which perforation followed injection of the paste, with infection and subsequent death.

West Middlesex Hospital, Isleworth, Middlesex

S. V. SOOD, F.R.C.S.ED., M.R.C.O.G., Senior Gynaecological Registrar
Dutra et al. (1950) reported on medicolegal investigations of seven cases of criminal abortion with four deaths. They described the postmortem findings and conducted experiments on rabbits, and showed that intravenous injections of the paste proved immediately fatal with focal haemorrhages in lungs. Subcutaneous infections caused necrosis of skin, subcutaneous tissues, and adjacent skeletal muscles, very similar to the necrosis of the uterine wall observed in one of the four fatal cases. Williams et al. (1955), in a series of 32 cases, reported one case each of pulmonary embolism, pulmonary oedema with intravascular haemolysis and haemoglobinuria, shock and renal damage, and haemoglobinuria with very mild jaundice. There were two cases of pelvic infection. These complications led them to abandon this method.

Döderlein, in a letter to Riddell (1932), cast some doubt on the accuracy of the causes of death in cases recorded owing to the paucity of pathological and microscopical evidence taken at necropsy.

Barns (1947) reviewed 71 cases. He described six cases of "pyrexia reaching morbidity standard" and "heavy blood loss" after abortion in four cases. Lachelin and Burgess (1968) were enthusiastic and reviewed 182 cases, reporting that not only was abortion successful in every case but there were no serious complications. Diggory (1969) reported on 59 cases of termination by utus paste-one patient had a severe intrauterine infection with rigors, three patients needed a second injection of paste, and in two cases hysterotomy had to be undertaken as abortion did not occur.

During 1968 and 1969 a commercially available Utus paste was used for induction of abortion at the West Middlesex Hospital in a tocal of 83 cases.

\section{Technique}

The patient was admitted to hospital and prepared for a vaginal operation. The premedication was ordered by the anaesthetist 